\title{
Hiding from the good guys
}

\author{
Brendon M. Stiles, MD
}

\footnotetext{
From the Department of Cardiothoracic Surgery, Weill Cornell Medical College, New York-Presbyterian Hospital, New York, NY.

Disclosures: B.M.S. has received consulting fees from Merck, and his spouse receives salary and stock options from Pfizer.

Received for publication Aug 11, 2017; accepted for publication Aug 19, 2017; available ahead of print Nov 7 , 2017.

Address for reprints: Brendon M. Stiles, MD, 525 East 68th St, Greenberg Pavilion, Suite M404, New York, NY 10065 (E-mail: brs9035@nyp.org).

J Thorac Cardiovasc Surg 2018;155:363-4

0022-5223/\$36.00

Copyright (C) 2017 by The American Association for Thoracic Surgery

http://dx.doi.org/10.1016/j.jtcvs.2017.08.060
}

Immunotherapy is a game changer for patients with metastatic lung cancer. Anti-programmed death 1 or anti-programmed death ligand 1 (PD-L1) antibodies are approved as first-line treatment for patients with newly diagnosed stage IV non-small cell lung cancer or as second-line treatment options. ${ }^{1-3}$ The question remains as how to best target these drugs to the population of patients most likely to respond, with conflicting results from published trials. Clearly, there is more to the targeting story than just PDL1 levels. If one recalls the complexity of the immune system learned in medical school, this should not be surprising. The bad guys (tumor cells) have plenty of opportunities to hide from the good guys (cytotoxic $\mathrm{T}$ cells). The challenge lies in figuring out how everything fits together for the individual patient. Many previous mechanistic studies have been performed in patients with advanced disease, often those who have been previously treated with chemotherapy. Arguably, these are not the ideal patients in whom to study progression of cancer and treatment response in an immune context. Therefore, it is critical that we turn our attention to studying the immune landscape in early-stage tumors, where the potential exists to better understand and target early immune system alterations that may facilitate cancer progression.

I congratulate Hirai and colleagues ${ }^{4}$ on their study of the prognostic impact of PD-L1 and human leukocyte antigen (HLA) class I expression in stage I lung adenocarcinoma. In their study of 94 patients, they found expression of PDL1 $(>1 \%)$ in only $22 \%$ of patients and "normal" expression of HLA class I molecules in only $57 \%$ of patients. Higher levels of PD-L1 expression $(>5 \%)$ correlated with worse overall survival, although PD-L1 expression was also seen more frequently with other adverse clinical and pathologic features. More interesting was that the poor prognosis of patients with PD-L1 was only apparent when their tumors expressed normal levels of HLA class I molecules. In other words, the ability to induce a T-cell checkpoint was only clinically relevant in tumors that presented antigens that could be recognized by cytotoxic $\mathrm{T}$ cells. field.

\section{References}

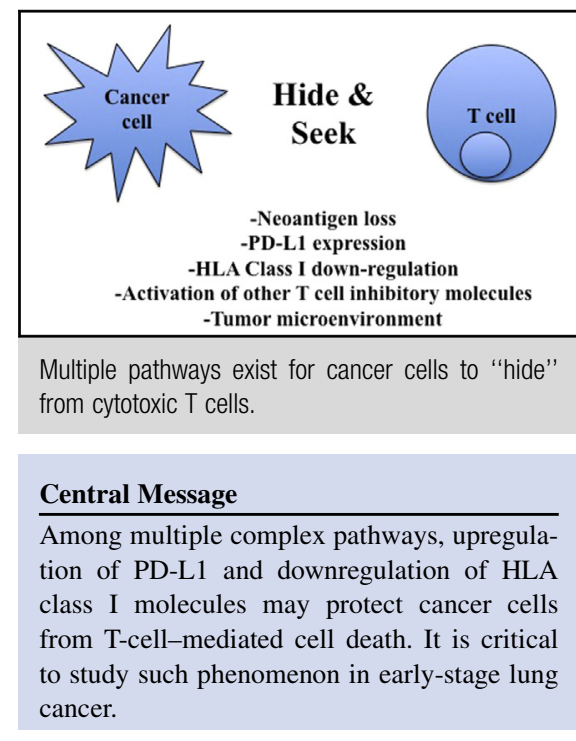

See Article page 382.

Downregulating HLA I molecules is one way tumor cells can "hide" from cytotoxic T cells, making PD-L1 expression less important. This seems entirely logical, despite the existing body of conflicting literature, nicely summarized by the authors in their "Discussion." "Such an "immunepermissive tumor microenvironment" induced by HLA class I expression has been previously described. ${ }^{5}$ Although this underpowered study, evaluating only overall survival and not disease recurrence, is by no means definitive or groundbreaking, it puts thoracic surgeons on the right pathway. Immunotherapy is being actively studied in several neoadjuvant (NCT02259621/NCT02998528) and adjuvant (NCT02504372/NCT02273375) trials in non-small cell lung cancer. It behooves surgeons not to hide from the trials or the complexity of the science, but rather to actively engage in the clinical and basic research opportunities that are afforded to us in this ever-expanding

1. Rittmeyer A, Barlesi F, Waterkamp D, Park K, Ciardiello F, von Pawel J, et al OAK Study Group. Atezolizumab versus docetaxel in patients with previously treated non-small-cell lung cancer (OAK): a phase 3, open-label, multicentre randomised controlled trial. Lancet. 2017;389:255-65.

2. Reck M, Rodríguez-Abreu D, Robinson AG, Hui R, Csőszi T, Fülöp A, et al; KEYNOTE-024 Investigators. Pembrolizumab versus chemotherapy for PD-L1positive non-small-cell lung cancer. N Engl J Med. 2016;375:1823-33.

3. Carbone DP, Reck M, Paz-Ares L, Creelan B, Horn L, Steins M, et al; CheckMate 026 Investigators. First-line nivolumab in stage IV or recurrent non-small-cell lung cancer. N Engl J Med. 2017;376:2415-26. 
4. Hirai A, Yoneda K, Shimajiri S, Kuroda K, Hanagiri T, Fujino Y, et al. Prognostic impact of PD-L1 expression in correlation with HLA class I expression status in stage I adenocarcinoma of the lung. J Thorac Cardiovasc Surg. 2018;155: 382-92.
5. Perea F, Bernal M, Sánchez-Palencia A, Carretero J, Torres C, Bayarri C, et al. The absence of HLA class I expression in non-small cell lung cancer correlates with the tumor tissue structure and the pattern of T cell infiltration. Int J Cancer. 2017;140: 888-99. 